\title{
Scholars and Literati at the University of Santiago de Compostela (1526-1800)
}

\author{
David de la Croix Gaia Spolverini
}

IRES/LIDAM, UCLouvain

This note is a summary description of the set of scholars and literati who taught at the University of Santiago de Compostela from its inception in 1526 to the eve of the Industrial Revolution (1800).

\section{The UNIVERSITY}

The origin of the University of Santiago de Compostela, located in the homonymous town in the Galicia, Spain, dates as far back as 1495, when a "grammar school (Colegio de Gramática)" for the poor was built in an old Monastery. In 1504, Pope Julius II's Bull formally approved the creation of a learning institution, however it was not until 1526 that Pope Clement VIII granted the city the right to enlarge the existing school and establish a university. Theology, law and humanities were the first departments to open. Education was strongly influenced by religion: the Jesuits took charge of teaching humanities in 1593 after several disputes (Herbermann 1913). With time, the university added new chairs in medicine and science. In the 18th century, it lost some autonomy, coming under stricter control from the Spanish Monarchy and in 1767 the Jesuits were banned from Spain. This completed the transition away from religious control of the university and is curriculum. Moreover, the Royal family supported the physical expansion of the university with a grant of land and buildings in Santiago.

\section{SOURCES}

The book "Historia de la Universidad de Santiago de Compostela" by Enrique Fernández Villamil and Salvador Cabeza de León (1947) is a comprehensive history of the University of Santiago de Compostela. It includes a detailed history of the athenaeum; its organizational structure, such as the statute and all the subsequent reforms; the faculty, with a detailed chronological compilation of all the appointed professors, and important facts and events, such as visits of distinguished historical figures. To complement these biographies, we used the dictionary from the Real Academia de la Historia (2020) and the Catholic Encyclopedia (Herbermann 1913).

\section{SOME STATISTICS}

Table 1 shows some descriptive statistics. There are 439 scholars and literati. The year of birth is known for $5.9 \%$ of them, which is a very low percentage. For the few people for whom the birth year is known, the mean age at appointment is 35.4 years. Longevity (mean age at death \& expected age at death when 30) is extremely high, with numbers above 70 for both indicators. This could be due to a selection effect: those for whom we know the vital dates are also those who lived longer. The birthplace is known for $15.5 \%$ of the individuals, again a very low number, as we were unable to find information about most of the scholars in the sample. The median distance between their birthplace and Santiago is $111 \mathrm{~km}$, and is higher for the first period. Finally, $1.4 \%$ of the scholars have a Wikipedia page (in some language), and only 3.6\% of them have left a footprint in the catalogs of the libraries of the world, Worldcat, either by having published work, or by having been the subject 
of published books and articles. Those two percentages are very low on average, and declining over the period considered.

\begin{tabular}{|c|c|c|c|c|c|c|}
\hline \multicolumn{2}{|c|}{ Period } & \multirow{2}{*}{$\begin{array}{l}\text { nb. } \\
\text { obs }\end{array}$} & \multirow{2}{*}{$\begin{array}{l}\text { \% birth year } \\
\text { known }\end{array}$} & \multirow{2}{*}{$\begin{array}{l}\text { mean age } \\
\text { at appoint. }\end{array}$} & \multirow{2}{*}{$\begin{array}{l}\text { mean age } \\
\text { at death }\end{array}$} & \multirow{2}{*}{$\begin{array}{l}\text { exp. age } \\
\text { at death }\end{array}$} \\
\hline Start & End & & & & & \\
\hline 1527 & 1617 & 79 & 8.9 & 40.3 & 70.1 & 70.5 \\
\hline 1618 & 1685 & 116 & 5.2 & 33 & 72.8 & 74.4 \\
\hline 1686 & 1733 & 117 & 5.1 & 26.6 & 68 & 68.8 \\
\hline 1734 & 1800 & 129 & 5.5 & 39 & 70.3 & 69.9 \\
\hline 1000 & 1800 & 439 & $\overline{5} . \overline{9}$ & 35.4 & $\overline{70.4}$ & 71.5 \\
\hline & & & $\begin{array}{c}\text { \% birthplace } \\
\text { known }\end{array}$ & $\begin{array}{l}\text { median distance } \\
\text { birth-institution }\end{array}$ & $\begin{array}{c}\% \text { with } \\
\text { Wikipedia }\end{array}$ & $\begin{array}{c}\% \text { with } \\
\text { Worldcat }\end{array}$ \\
\hline 1527 & 1617 & & 13.9 & 213 & 2.5 & 6.3 \\
\hline 1618 & 1685 & & 19 & 85 & 1.7 & 5.2 \\
\hline 1686 & 1733 & & 17.1 & 95 & 0.9 & 0.9 \\
\hline 1734 & 1800 & & 11.8 & 95 & 0.8 & 3.1 \\
\hline 1000 & 1800 & & 15.5 & 111 & 1.4 & $\overline{3} . \overline{6}$ \\
\hline
\end{tabular}

Table 1: Summary statistics by period

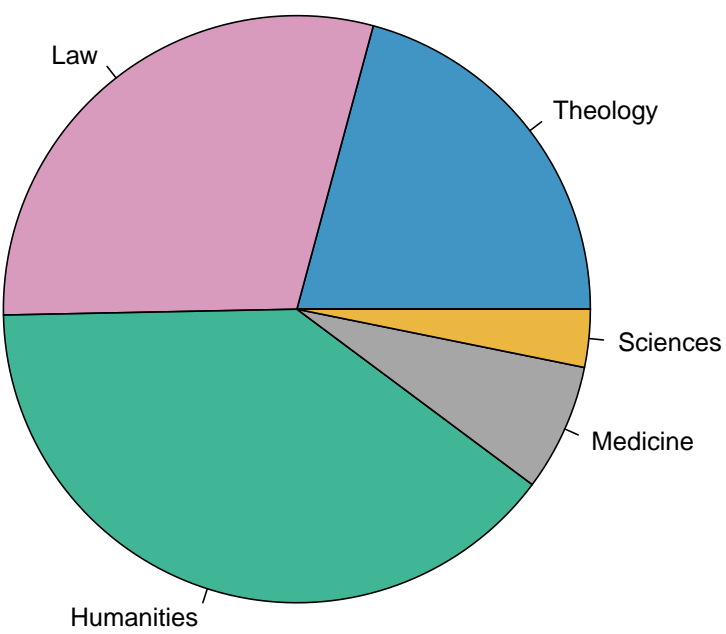

Figure 1: Broad fields at University of Santiago de Compostela

\section{FIELDS}

Figure 1 shows the relative importance of fields. The University started as a rather small institution: Cabeza de León and Fernández-Villamil (1947) mentions that there were only three chairs per field, namely Humanities, Theology and Law. Thanks to the gradual independence from the religious orders the faculty became more diverse. There were new chairs in the fields of Science and Medicine, although these fields remained small in number compared to the rest of the faculty. 


\section{Place OF BIRTH}

Figure 2 is a plot of the places of birth of all the scholars of Santiago de Compostela. The North-West regions of Spain dominate. The number of scholar coming from elsewhere in Spain is negligible. The university does not attract international scholars, and even its reach within Spain is limited. It is essentially a Galician university.

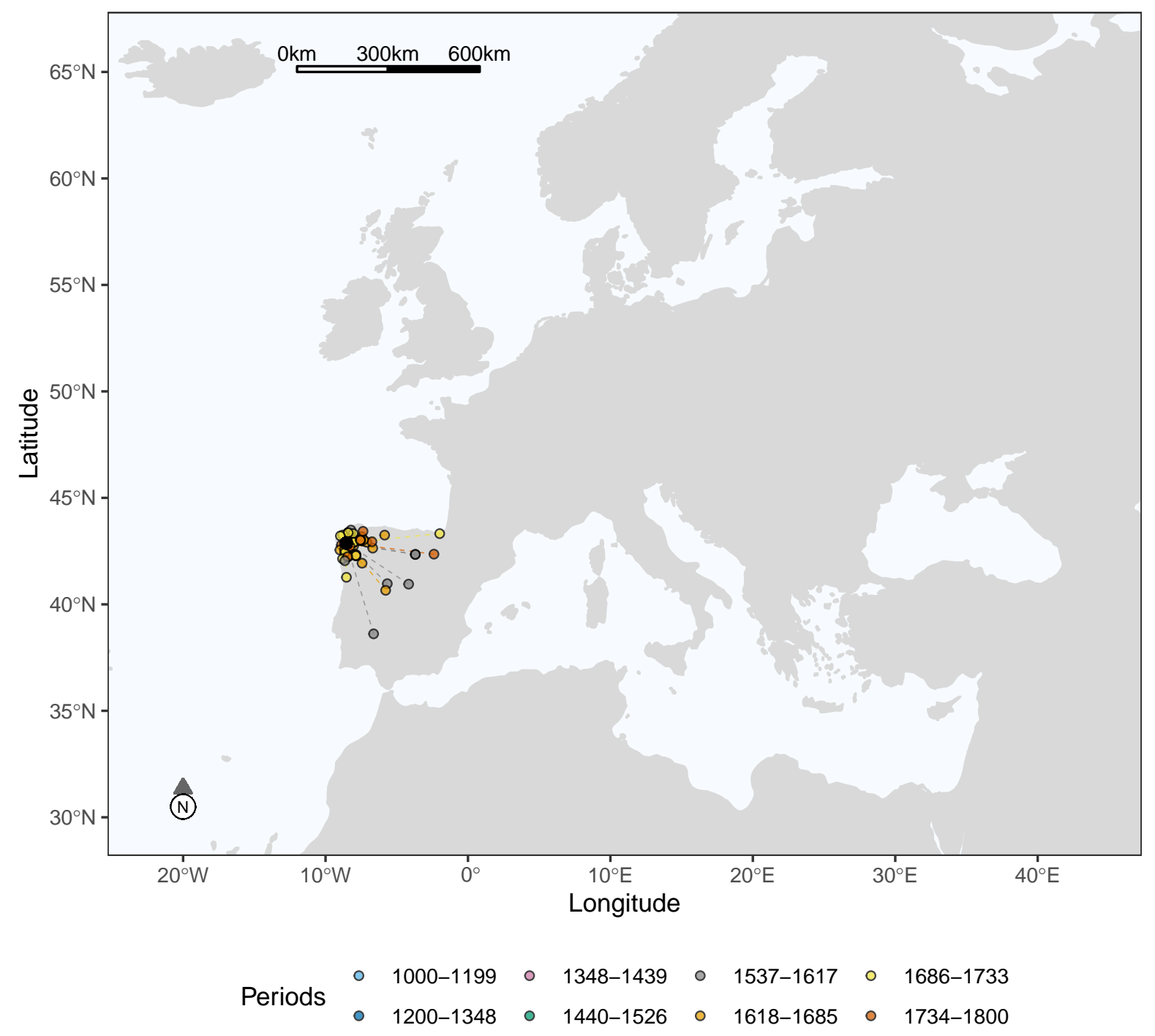

Figure 2: Place of birth of the scholars and literati at the University of Santiago de Compostela

\section{HUMAN CAPITAL OF SCHOLARS AND LITERATI}

For each person in the database we compute a heuristic human capital index obtained by combining information from Worldcat and Wikipedia using a principal component analysis. We also compute the notability of the university at each date by averaging the human capital of the scholars active in Santiago de Compostela 25 years before that date. Details are given in the Appendix. Figure 3 shows the names of all the scholars with a positive human capital index. The orange line plots the notability of the university. 


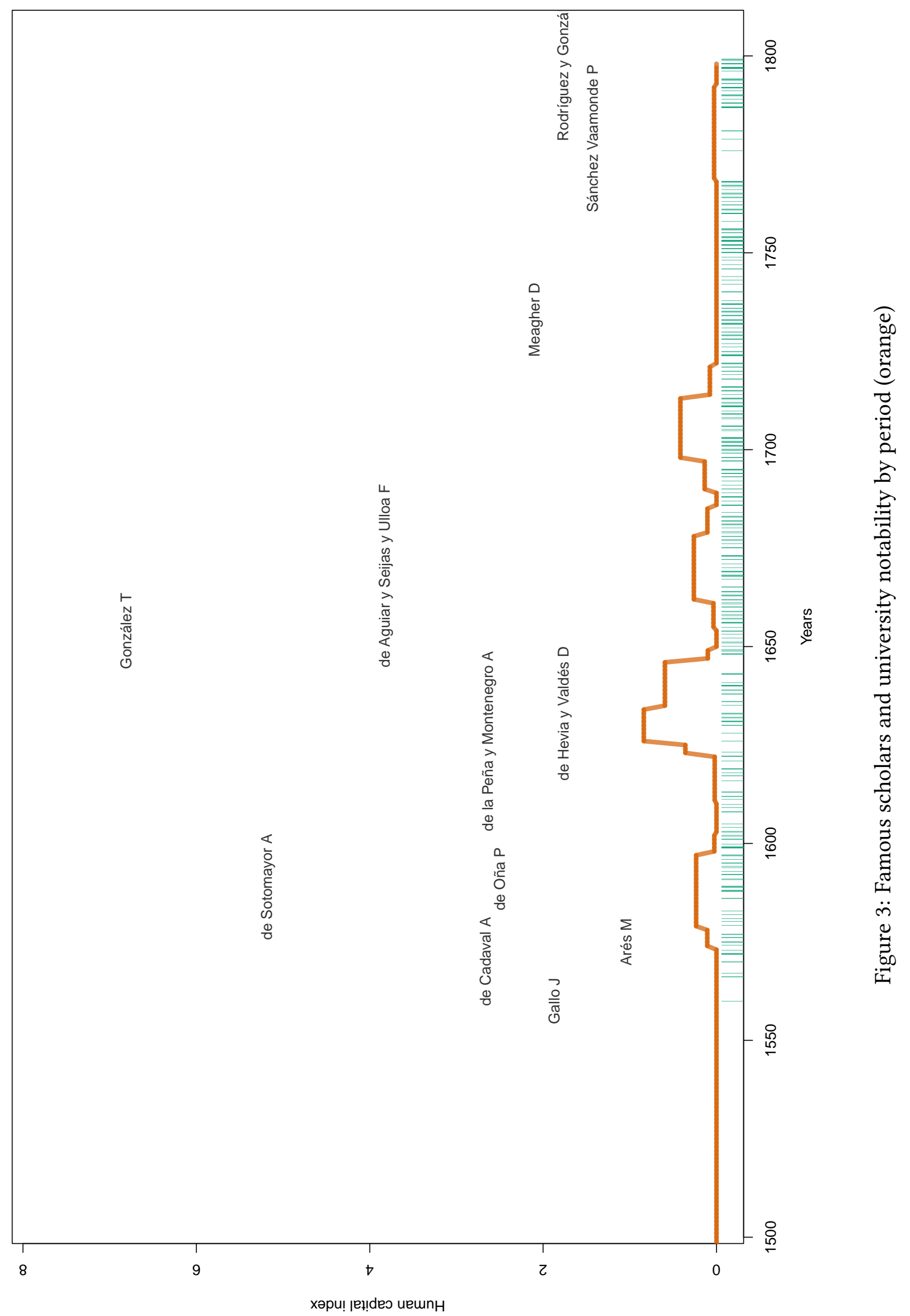


The pattern is one of a very weak university. Despite the very large number of individuals listed in Cabeza de León and Fernández-Villamil (1947), represented by the vertical green lines, Figure 3 is rather empty. Moreover, when comparing this graph with that of other universities, notice that the scale of the vertical axis may not be the same. Here, the range is $(0,6)$, while for top universities, we have a scale of $(0,14)$ to accommodate several scholars with an index between 6 and 14 . Hence in Santiago de Compostella there are a few known people and a mass of obscure professors who left little or no publications at all. The resulting notability of the university (orange line) is fairly constant over time and close to zero.

\section{TOP 6 PROFESSORS}

We now provide a brief overview of the six professors with the highest human capital index.

Tirso González (Arganza 1624 - Rome 1705) was a prominent Jesuit priest who graduated in theology and philosophy in Salamanca and Santiago. He became professor of philosophy in Santiago in 1653. In 1687, he was appointed as the thirteenth Superior General of the Society of Jesus. He published several papers concerning the debate between the doctrine of probabilism and probabiliorism, as well as some apologethic works.

Antonio de Sotomayor (Santo Tomé de Freijeiro 1557 - Madrid 1648), was an ecclesiastic belonging to the Dominican order who taught theology in Santiago from 1589 to 1601 . He held several important religious and political positions, including confessor of King Philip III and his family. From 1629, he also served as Grand Inquisitor of Spain.

Francisco de Aguiar y Seijas y Ulloa (La Coruña 1632 - Mexico City 1698) was an important ecclesiastic who became Rector of the University of Santiago between 1668 and 1674. After studying and teaching in Salamanca, he was appointed Bishop of Michoacán, Mexico, and then Archbishop of New Spain by Pope Innocent XI. In Mexico, he carried out charitable work and contributed to the founding of the Conciliar Seminary of Mexico, an institution that trained men for the priesthood in New Spain.

Alonso de la Peña y Montenegro (Padrón 1596 - Quito 1687) was a prominent scholar who became professor of theology in Santiago in 1623, after completing his studies. He became priest in 1632 and was chosen by the King of Spain Felipe IV and Pope Innocent X as Bishop of Quito in 1653, where he served until his death.

Álvaro de Cadaval (Tuy 1505 - Santiago de Compostela 1575) was a famous humanist who became a lecturer of Latin in Santiago in 1542. He moved to Portugal and affiliated with University of Coimbra; he was later accused of heresy and imprisoned for a few months. He returned to Santiago in 1570, where he taught until 1573, when his health worsened significantly (Herbermann 1913).

Pedro de Oña (Burgos 1560 - Gaeta 1626) was a philosopher and theologian who studied in Salamanca and then taught in Compostela around 1593. He was nominated by King Felipe III and Pope Clement VIII to be the Bishop of Caracas, and although he was consacrated to the position, he never made the journey to Caracas. The King later appointed him as Bishop of Gaeta in Italy, and he served there until his death.

Herbermann (1913) provides its own list of top scholars: "Among the distinguished professors of the university may be mentioned Pedro de Vitoria and Alvaro de Cadabal, and in the second epoch Villagran and Jose Rodriguez y Gonzalez, professor of mathematics, appointed by the Emperor of Russia to direct the observatory of St. Petersburg, and associated with Blot and Arago in the measurement of the meridional circle, and many others." Among the four names, we were not able to identify Pedro de Vitoria and Villagran. Alvaro de Cadabal (or Cadaval) was not listed in our main source, but we found information confirming his presence at the University of Santiago de 
Compostela. He appears in our ranking in position \#5. We also added Jose Rodriguez y Gonzalez, although he acted as a "catedrático suplente", replacing temporarily someone else. He did not publish enough to appear in our top list.

\section{APPENDIX}

The individual human capital index $q_{i}$ of an individual $i$ is given by:

$$
\begin{aligned}
q_{i}= & -1.76+0.43 \ln (\mathrm{nb} . \text { characters of the longest Wikipedia page }) \\
& +0.40 \ln (\mathrm{nb} . \text { Wikipedia pages in different languages })+0.47 \ln (\text { nb. works in Worldcat }) \\
& +0.46 \ln (\mathrm{nb} . \text { publication languages in Worldcat })+0.47 \ln (\mathrm{nb} \text {. library holdings in Worldcat })
\end{aligned}
$$

We assume that having no Wikipedia page is similar to having one page with a length of 60 characters and that having no Worldcat page is similar to having a page with one work in one language held by one library. The constant -1.76 normalizes $q_{i}$ at 0 when there is neither a Wikipedia page, nor a Worldcat page. The weights $(0.43,0.40$, etc) are obtained from the first principal component of the five indicators (De la Croix et al. 2020).

The notability $Q$ of a university aggregates the $q$ of the top 5 persons who were active in the preceding 25 years using the following formula:

$$
Q=\sqrt{\sum_{i=1}^{5} \frac{1}{5}\left(\frac{q_{i}}{s_{i}}\right)^{2}}
$$

where $s_{i}$ is the number of universities in which $i$ had an appointment.

\section{ACKNOWLEDGMENTS}

This project has received funding from the European Research Council (ERC) under the European Union's Horizon 2020 research and innovation programme under grant agreement No 883033 "Did elite human capital trigger the rise of the West? Insights from a new database of European scholars."

First version March 19, 2021.

\section{REFERENCES}

Cabeza de León, Salvador, and Enrique Fernández-Villamil. 1947. Historia de la Universidad de Santiago de Compostela. Peón,.

De la Croix, David, Frédéric Docquier, Alice Fabre, and Robert Stelter. 2020. "The Academic Market and the Rise of Universities in Medieval and Early Modern Europe (1000-1800).” CEPR Discussion Paper 14509.

Herbermann, Charles George. 1913. The Catholic Encyclopedia. New York: Encyclopedia Press, Incorporated.

Real Academia de la Historia. 2020. Diccionario biográfico español (online version at https:// dbe.rah. es). Madrid: Real Academia de la Historia. 